\title{
An Evaluation of the Current English Language Curriculum in Nigerian Secondary Schools
}

\author{
Oribabor, O. A PhD \\ Institute of Education, Faculty of Education Obafemi \\ Awolowo University, Ile - Ife. Osun state, Nigeria \\ bisioribabor2006@yahoo.com
}

\section{Doi:10.5901/jesr.2014.v4n6p295}

\begin{abstract}
This research evaluated the new English Language Curriculum in Nigerian Secondary Schools. Among variables investigated were the cultural relevance of the contents, the extent to which the objectives of tile programme are practically feasible and the availability of recommended instructional materials. Subjects for the study were 150 Senior Secondary School pupils in both Urban (ile-lfe) and Rural (Ibodi) areas respectively of former Oramiyan and Atakumosa Local Government Areas respectively. The ages of the senior secondary school students ranged from seventeen year six months to eighteen years three months. An attitude scale and a questionnaire were used to test the relationship among the variables identified for the study. Data collected in the study were analysed using percentages and t-test the six hypotheses generated for the study. The hypotheses were tested at .05 level of confidence. The findings of the study suggested that there is the need to introduce topics that are culturafly relevant to the student background. The non-availability of recommended instructional materials suggests the need for an urgent reassessment of existing strategies for implementing the new English language programme.
\end{abstract}

\section{Introduction}

The paper was written to examine the Nigerian Secondary School New English Language Curriculum and to investigate in particular, the relevance, and appropriateness of the senior secondary school current English language curriculum.

Teachers' experience when implementing the programme suggests that some of the objectives are not achievable because, the contents are probably culturally irrelevant and in most cases are at variance with the background knowledge of the Nigerian senior secondary school students.

Cultural and socio-economic background of the learners and the methodologies adopted in the class are also inadequate. These and other factors might have contributed to the mass failure among students reported by Banjo 1985. Evidence to show that performances of candidates in WAEC OIL and A/L examinations have been observed to deteriorate, in recent years are available in the school WAEC analysis.

Empirical investigations of the effects of these factors are rare. Therefore, before the situation gets out of control empirical studies are necessary. Therein lies the rationale for this paper. The significance of this paper lies in providing information that will be useful in dealing with problems.

The English language is regarded as the backbone of all other subjects taught in secondary school, because English language is the medium of instruction in most secondary and tertiary institutions of formal learning in Nigeria. In fact the English language is one of the few core subjects recommended for secondary schools in the National Policy on Education (National Pohcy, 1981). It is, therefore, an essential pre-requisite for further education. At least a pass (P7) in English is a requirement even for science - based students.

Because of the emphasis placed on passing English language ' 0 ' level in the Nigerian educational system, it is essential that the language is properly taught so that pupils can have effective mastery of the subject. Our political and social circumstances make the use of English language imperative not only as a foreign language but an official language.

Teachers' experience when implementing the programme suggests that some of the objectives are not achievable because, the contents are probably culturally irrelevant and in most cases are at variance with the background knowledge of the Nigerian Senior Secondary School students. Cultural and socio-economic background of the learners and the methodologies adopted in the class are also inadequate. These and other factors might have contributed to the mass failure among students reported by Banjo (1985). 
In the light of the aforementioned the following objectives were addressed in this paper.

\section{Objectives of the Study}

The objectives of the study are as stated below:

1. Investigate the cultural relevance and practical feasibility of the objectives of the secondary school English language curriculum.

2. Assess the availability of recommended instructional materials in selected rural and urban schools.

3. Compare the interest of students in rural and urban settings in terms of the English language curriculum.

The study was carried out in secondary schools in Ife South, Central and North Local Government Areas. The study is limited to English language teachers who are the implementers of the New English Language Programme.

\section{Sample of the Study}

The subjects for the study consisted of 150 senior secondary year I students drawn from four secondary schools in both urban lle-lfe and rural Ibodi areas. The ages of the students range from seventeen years six months to eighteen years three months.

\section{Instrumentation}

Two instruments were developed for the study, these are Teachers and students questionnaires. The teachers attitudinal questionnaire which contains sixteen items grouped into three categories designed to solicit teachers responses on (1) cultural relevance, and (2) availability of instructional materials.

Reliability of items in the questionnaire of the Teachers and students are established at 0.75 and 0.78 respectively using the Kuder Richardson Formula.

The validity of the instruments was established by the assistance of four experienced English language teachers involved in the teaching of the senior secondary school new English language curriculum and a curriculum expert knowledgeable about the objectives of the study.

Originally, the Teacher's Questionnaire contained 24 items,

But after the comments and suggestions of experts involved in the validation only 16 items finally survived the scrutiny of the experts. Also there were 36 items in the original version of the students' questionnaire but was reduced to 25 after the comments and suggestions of the experts involved in the validation process.

\section{Data Collection}

The Teachers questionnaire was administered to 25 teachers in urban and 25 teachers in rural schools. The students' instrument scale was also administered to 150 students (75 in urban and 75 in rural schools). An administration of the instruments to the students was carried out in normal classroom settings. In both administrations colleagues in the respective schools assisted in collecting the subjects responses.

\subsection{Hypothesis 1}

There is no significant difference between the opinion of teachers in rural and urban settings on the cultural relevance of the secondary school new English language curriculum. This hypothesis was analysed using percentage and t-test statistic.

Table 1: Responses by Teachers of Urban and Rural setting on Cultural Relevance

\begin{tabular}{|l|c|c|c|c|}
\hline Subject & $\mathrm{N}$ & Mean & Standard deviation & $\mathrm{t}$ \\
\hline Urban Teacher (Yes) & & 3.8 & 4.8 & \multirow{2}{*}{$-8.53^{*}$} \\
Rural Teacher (Yes) & & 6.2 & 5.0 & \multirow{2}{*}{8.53} \\
\hline Urban Teacher (no) & & 21.2 & 4.8 & 5.0 \\
Rural Teacher (No) & & 18.8 & \\
\hline
\end{tabular}

$\mathrm{N}=(25)=$ Statistically significant difference at the 0.05 level * $p=0.05$ 
It is clear from the responses of teachers to this particular item that most of the teachers (i.e. eighty percent) are of the opinion that the topics in the new 3nglish language curriculum are not culturally relevant to the pupils background. The result of these analyses show that there is need for the topics to be culturally related to the students background. It must have been observed that there is a general consensus among teachers in both urban and rural schools that there is genuine need for cultural relevance in planning the new English language programme. Personal interviews with the teachers reveal that the teachers are having some difficulties in teaching the topics because most of the topics are said to be alien to their own cultural background. Most of the teachers had never come in contact with some of the recommended topics before e.g. Dairy farming, stock- exchange bureau. In addition, the teachers indicated that orientation workshop session which could have introduced them to the objectives and methods of teaching of the new programme were non-existent.

In short, it would appear that most of the teachers interviewed felt that some topics (e.g. visit to a diary farm, or stock exchange bureau) in the document could be omitted and something else should take their place. Findings from those analyses have therefore indicated a major shortcoming at the planning stage.

\subsection{Hypothesis II}

There is no significant difference in the opinion of teachers in rural and urban settings on the practical feasibility of the objectives of the secondary school new English language curriculum.

This hypothesis was analyzed using percentage and t-test statistic.

Table 2: Practical Feasibility of Objectives

Responses of Teacher Sin Urban and Rural Setting on the Practical Feasibility of the Objectives of the New Document $\mathrm{N}=(25)$

\begin{tabular}{|l|c|c|c|c|}
\hline Subject & $\mathrm{N}$ & Mean & Standard deviation & $\mathrm{t}$ \\
\hline Urban Teacher (Yes) & & 14 & 11.3 & \multirow{2}{*}{14.17} \\
Rural Teacher (Yes) & & 7 & 2.8 & \multirow{2}{*}{-14.17} \\
\hline Urban Teacher (no) & & 11 & 11.3 & 2.8 \\
Rural Teacher (No) & & 18 & & \\
\hline
\end{tabular}

$=$ Statistically significant difference at the 0.05 level ${ }^{*}=0.05$

The second objective requires the student to speak satisfactorily in their places of work, it will be easier to achieve that objective by giving students topic which are part and parcel of the students' daily life so

And under class activities they are supposed to 'Describe some byproducts of animal husbandry e.g. milk, cheese, pork, beef p.e. Where in Nigeria are the dairy cows for them to see? In the absence of this practical experience how can they 'talk and write effectively' on the practical experience they never had?

Bearing in mind one of the specific objectives of this research which is to investigate practical feasibility of the objectives, and methods and approaches of teaching recommended in the programme, teacher were requested to respond to item 8 as to whether or not the objectives are achievable that learning becomes meaningful and concrete rather than abstract. According to the National Curriculum for Senior Secondary Schools performance objective associated with dairy farming states:

\subsection{Hypothesis III}

There is no significant difference between the schools in rural and urban settings in the availability of recommended instructional materials.

This hypothesis was analyzed using percentage and t-test statistic. 
Table 3: Responses by teachers of urban and rural areas on the availability of recommended instructional materials in the new curriculum

\begin{tabular}{|l|c|c|c|c|}
\hline Subject & $\mathrm{N}$ & Mean & Standard deviation & $\mathrm{T}$ \\
\hline Urban Teacher (Yes) & & 1.5 & 5.1 & $-1.57^{*}$ \\
Rural Teacher (Yes) & & 2 & 5.8 & \multirow{2}{*}{$1.57^{\star}$} \\
\hline Urban Teacher (no) & & 23.5 & 5.1 & 5.8 \\
Rural Teacher (No) & & 23 & & \\
\hline
\end{tabular}

* $P=0.05$

\subsection{Availability of instructional material}

On the issue of instructional materials related to the programme are not available only twenty-four percent or 6 of the teachers in urban area indicated that the instructional materials are available. In contrast seventy-six percent or 19 of the teachers indicated that the instructional materials are not usually available.

In the rural area, as indicated in Table 5, twenty-eight percent or 7 of the teachers indicated that the instructional materials are available. In summary, twenty-six percent of all teachers in urban and rural areas indicated that instructional materials are not available.

There is need to have a closer look at the new English language curriculum so that topic recommended are those that teachers can easily get instructional materials For, This will facilitate effective learning. This point is very crucial in evaluation and it is one of the stated areas for investigation. The questions grouped under this heading were thoroughly anlaysed individually. In the preamble to the new document item 5 under spoken English states that:

"The aim of this component of the syllabus is to ensure that students become competent speakers of English" p. vii.

\section{Conclusion and Recommendation}

The pupils are pioneering pupils of the programme (SSS1).

The analysis of the collected data was carried out by using descriptive mean-score and t-test. It was found that:

(1) there was difference ( $t=0.05$ for "Yes" among urban and rural teachers) and $t=8.53 ; p=0.05$ for "No" in urban and rural teachers) on the cultural relevance of the new English language

(2) there was significant difference $(t=13.78)$ for Yes in urban and rural teacher) $t=13.47$ for No in urban and rural teachers on the practical feasibility of the objectives of the new document.

(3) there was no difference ( $t=$ Yes in urban settings) ( $t=$ in urban settings a $v$ a lab ty

Recommended instructional materials.

\section{Conclusion}

The findings of this study suggest that there is need for a total re-visiting of the new English language curriculum in those areas dealing with cultural relevance, practical feasibility of objectives and availability of recommended instructional materials in the new English language curriculum.

\section{Recommendation}

The content of the new English language programme should incorporate cultural values.

Teachers should make use of recommended experts when and where available, so that teaching can become meaningful. There is need for modification of the affected topics in the existing textbook to make the text culturally relevant. 


\section{References}

Afolayan, A. (1984) "What English as a language?" In A. (ed) English as language, Vol.1.

Akintola, A. (1988) "An Assessment of the New National English Curriculum For The Nigerian Senior Secondary School As A Basis For Communicative English Teaching". IFE STUDIES IN ENGLISH LANGUAGE Vol. 2 No 2 September.

Banjo, A. (1988) Don Blames West African Examination ofEducation, National Concord February.

Banjo, A. (1974) "On the State of English Studies" Nigeria Journal of the Nigerian

English Studies Association JNSEA Vol. 6 No 1. May.

Barnes, D. (1982) Practical Curriculum Study London: Routledge \& Kegan Paul Educational,

Bloom, B.S. (1956) Taxonomy of Educational Objectives 1: Cognitive Domain London: Long man Appointed by the Secretary of State For Education and Science London H,M.S.O.

Bullock, F.B.A. (1975) A For Life Report Committee of Language of the Inquiry appointed by the secretary of state for education and science London H.M.S.O

Bumpass, FL. L. (1963) Teaching 'Young Children Engflsh Ps P Foreign Language New York: American Book Company

Blyth, W.A.L. (1976) Place, Time and Society Bristol Collins ESL.

Bruner, i_s. (1966) Towards a Theory of Instruction, Cambridge, Mass, Harvard University Press.

Chastain, K, (1971) The Development of Modern Language Skill, Theory to Practice Philadephia: The Centre for Curriculum Development.

Cook, A.W. (1951) Minnesota Teacher Attitude Inventory New York: The Psychological Corporation.

Cowain, S. (1967) English Proficiency and Bi-cultural attitudes of Japanese Studies CERIC: ED. 27529.

Curran, C. (1961) "Counselling Shills to the learning of Foreign Languages" Bulletin of Mear:inger Clinic Xxv. 2

Department Science of the H M SO. of Education and (DES) 198Db A view Curriculum, London HMSO

Department of Education and Science 198Db A framework for the School Curriculum London HMSO.

Department of Education and Science 1981 The School Curriculum London HMSO.

Federal Ministry of Education, 1985 National Curriculum for Senior Secondary Schools, Lagos Nigeria Vol. 2.

Finonocchiaro, M. 1971 Myth and Reality in TESOL. A plea for a Broader View Tesol Quarterly Vol. 2 March.

Gagne, R. (1965) The Conditions of Learning. Second Edition London: Holt, Rinehart and Winston.

Halliday, M.A.K. 1978 Language as a social semiotic. The social interpretation of language and meaning. London Edward Arnold.

Husband, J. D.A. 1945 A Technique for the Evaluation of Growth in Certain Affective Phases of Reading Among High School Pupils Journal of Educational Research Vol. 39, No 4 pp. 265-269.

Isaac, S. and MICHAEL, W.B. 1977 Handbook in Research and Evaluation Edits Publishers, San Diego, California.

Klen, W. 1986 Second Language acquisition Cambridge University Press Cambridge.

Macdonald, T.E. Psychology Wadsworth Company. 1965 Educational Belmont Publishing company

Marland, M. 1977 Language Across The Curriculum HeinernannLondon.

Mannheim, K. 1936 Ideology and Utopia, An introduction to the Sociology of knowledge. London Routledge and Kegan Paul.

Sapire, F. 1961 In Culture, Language and Personality Mandelbaum, D.C. (ed)University of California Press Scriven, M. 1973 'Goal-free evaluation' in ER. House (ed) Social Evaluation, The Politics, Process BerkeleyCa; McCutchan.

Shipman, M.D.D. (1982) The Limitations of Social Research 2nd edn; London Longman.

Shipman, M.D.D. (1983) Assessment in Primary and Middle Schools, Groom Helm, London.

Skinner, B.F. (1968) The Technology of Teaching New York: Appleton Century Crofts.

Spolky, 3. (1969) Attitude Aspects of Second Language Learning, Language Learning xix 4 December.

Stale, RE. (1960) Language, rationahty and assessment in W.H. Beatty (ed) Improving Educational Assessment Alexandria Va; Association for supervisor and Curriculum

Stenhouse, D. (1975) An Introduction to Curriculum Research and Development, Heinmann London.

Stern, G.G. (1963) Measuring Noncognitive Variable, A Handbook of Research in Teaching ed. N.L. Cage Chicago, R. and McNally and Company.

Olson, H.P. Evaluating Growth in Language ability Journal of Educational Research vol. XXXIX No. 4

Quirk, R. Greenbaum, S. Leech, G. and Svartvik, J.A. 1972 Grammar of Contemporary English London, Longman.

Whorfian, B.L. (1969) In The Psychology of Language, Thought and Instruction, J.P. Dc Ceeco (ed) Holt Rinehart and Winston U.S.A. 
ISSN 2239-978X

ISSN 2240-0524
Journal of Educational and Social Research MCSER Publishing, Rome-Italy
Vol. 4 No. 6 September 2014 